\title{
Microstructure and Oxidation Behavior of Anti-Oxidation Coatings on Mo-Based Alloys through HAPC Process: A Review
}

\author{
Tao Fu, Kunkun Cui, Yingyi Zhang * (D), Jie Wang, Xu Zhang, Fuqiang Shen, Laihao Yu and Haobo Mao
}

Citation: Fu, T.; Cui, K.; Zhang, Y.; Wang, J.; Zhang, X.; Shen, F.; Yu, L.;

Mao, H. Microstructure and

Oxidation Behavior of Anti-Oxidation Coatings on Mo-Based Alloys through HAPC Process: A Review. Coatings 2021, 11, 883. https:// doi.org/10.3390/coatings11080883

Academic Editor: Pier Luigi Bonora

Received: 24 June 2021

Accepted: 21 July 2021

Published: 23 July 2021

Publisher's Note: MDPI stays neutral with regard to jurisdictional claims in published maps and institutional affiliations.

Copyright: (c) 2021 by the authors. Licensee MDPI, Basel, Switzerland. This article is an open access article distributed under the terms and conditions of the Creative Commons Attribution (CC BY) license (https:/ / creativecommons.org/licenses/by/ $4.0 /)$.
School of Metallurgical Engineering, Anhui University of Technology, Maanshan 243002, China; ahgydxtaofu@163.com (T.F.); 15613581810@163.com (K.C.); wangjiemaster0101@outlook.com (J.W.); zx13013111171@163.com (X.Z.); sfq19556630201@126.com (F.S.); aa1120407@126.com (L.Y.); L1499923420@163.com (H.M.)

* Correspondence: zhangyingyi@cqu.edu.cn; Tel.: +86-173-7507-6451

\begin{abstract}
Mo and Mo-based alloys are important aerospace materials with excellent high temperature mechanical properties. However, their oxidation resistance is very poor at high temperature, and the formation of volatile $\mathrm{MoO}_{3}$ will lead to catastrophic oxidation failure of molybdenum alloy components. Extensive research on the poor oxidation problem has indicated that the halide activated pack cementation (HAPC) technology is an ideal method to solve the problem. In this work, the microstructure, oxide growth mechanism, oxidation characteristics, and oxidation mechanism of the HAPC coatings were summarized and analyzed. In addition, the merits and demerits of HPAC techniques are critically examined and the future scope of research in the domain is outlined.
\end{abstract}

Keywords: molybdenum alloys; coating; oxidation; microstructure; mechanism; review

\section{Introduction}

Mo and its alloys have high melting point, excellent high-temperature mechanical properties, low thermal expansion coefficient and high conductivity and thermal conductivity, which have been widely used in high-temperature structural components in national defense industry, aerospace, and other fields, such as nozzle throat, high temperature electrode, high-temperature heating element, ray shielding material, etc. [1-4]. However, the oxidation resistance of Mo and Mo-based alloys is very poor, and they are easily oxidized to $\mathrm{MoO}_{3}$ at a temperature of $\left(400-800{ }^{\circ} \mathrm{C}\right)[5,6]$. With the formation of $\mathrm{MoO}_{3}$, the volume of molybdenum alloy increases rapidly, and leads to the occurrence of low temperature pulverization phenomenon, namely "Pesting oxidation". In addition, the formation of a large amount of volatile $\mathrm{MoO}_{3}$ will lead to the catastrophic decomposition of molybdenum and its alloys when the oxidation temperature is greater than $1000{ }^{\circ} \mathrm{C}$ [7-10]. At present, alloying and surface coating can be used to improve the oxidation resistance of Mo and its alloys. Alloying is regarded as the preferred method to improve the properties of pure Mo, and Mo-based alloys have better mechanical properties than pure Mo when used at a high temperature above $1000^{\circ} \mathrm{C}$ [11-14]. The classification, preparation method, properties, and application fields of molybdenum-based alloys are shown in Table $1[15,16]$. Because of limitations of alloying capability of Mo, its high temperature oxidation resistance cannot be fundamentally improved by alloying. Therefore, surface coating technology is regarded as an ideal method to improve the high-temperature oxidation resistance of molybdenum and its alloys [17-19]. Among them, the HAPC technology is the most widely used. At present, there are many reports about the oxidation behavior of HAPC coatings on Mo and its alloys. However, almost no reviewing of the progress in development of oxidation resistance of Mo has been documented [20]. 
Table 1. Classification and application of Mo-based alloys.

\begin{tabular}{|c|c|c|c|c|c|}
\hline Alloy Type & Preparation Method & $\begin{array}{c}\text { Brand } \\
\text { Number }\end{array}$ & Performance & Application Field & Refs. \\
\hline Mo-Cu alloy & $\begin{array}{l}\text { Co-deposition method; } \\
\text { Metal oxide } \\
\text { co-reduction, etc. }\end{array}$ & $\mathrm{Mo}-\mathrm{Cu}$ & $\begin{array}{l}\text { Good conductivity, } \\
\text { thermal conductivity, } \\
\text { ablation resistance, high } \\
\text { hardness and strength }\end{array}$ & $\begin{array}{l}\text { Electrician and electronics, } \\
\text { instrumentation, national } \\
\text { defense and military } \\
\text { industry, aerospace, etc. }\end{array}$ & [15] \\
\hline Mo-Ti-Zr alloy & $\begin{array}{l}\text { Powder metallurgy; } \\
\text { Smelting process }\end{array}$ & TZM, TZC & $\begin{array}{l}\text { Excellent high } \\
\text { temperature strength, } \\
\text { high recrystallization } \\
\text { temperature, good heat } \\
\text { conduction and } \\
\text { corrosion resistance }\end{array}$ & $\begin{array}{l}\text { It is widely used in } \\
\text { aerospace fields, such as } \\
\text { rocket nozzles, nozzle } \\
\text { throat liners, valve bodies, } \\
\text { gas pipelines, etc. }\end{array}$ & [16] \\
\hline Mo-Re alloy & $\begin{array}{l}\text { Powder metallurgy; } \\
\text { Vacuum smelting }\end{array}$ & $\begin{array}{l}\text { Mo-5Re, } \\
\text { Mo-41Re, } \\
\text { Mo-50Re }\end{array}$ & $\begin{array}{l}\text { Excellent radiation } \\
\text { resistance and high } \\
\text { tensile strength, good } \\
\text { manufacturability and } \\
\text { high temperature creep } \\
\text { resistance }\end{array}$ & $\begin{array}{l}\text { Aerospace, nuclear energy, } \\
\text { chemical, electronics, } \\
\text { military and so on. }\end{array}$ & [17] \\
\hline $\begin{array}{l}\text { Rare earth } \\
\text { Mo alloy }\end{array}$ & Powder metallurgy & $\begin{array}{l}\text { Mo-0.5Ti-Y, } \\
\text { Mo-La, etc. }\end{array}$ & $\begin{array}{l}\text { Good toughness, high } \\
\text { temperature resistance, } \\
\text { good bending resistance } \\
\text { and tensile strength }\end{array}$ & $\begin{array}{l}\text { High temperature furnace } \\
\text { heating elements, nuclear } \\
\text { materials, glass melting } \\
\text { electrodes, etc. }\end{array}$ & [18] \\
\hline
\end{tabular}

In this work, the advantages and disadvantages of the HAPC coatings are summarized and analyzed. The composition, exposure time, exposure temperature and mass change per unit area of the coatings have been given in relevant tables [21,22]. Their oxide growth mechanism and oxidation behavior are emphatically analyzed and summarized. Finally, the oxidation resistance and failure mechanism of the coatings are also summarized, aiming to provide some useful references for researchers in this field [23].

\section{Microstructure and Growth Mechanism of HAPC Coatings}

Halide activated pack cementation (HAPC) method is to embed the substrate into a mixture (Si powder, $\mathrm{B}$ powder, $\mathrm{Al}$ powder, $\mathrm{NH}_{4} \mathrm{Cl} / \mathrm{F}, \mathrm{Y}, \mathrm{NaF}, \mathrm{Al}_{2} \mathrm{O}_{3}$ powder, etc.) with a certain particle size and proportion, and carry out thermal diffusion in vacuum or argon atmosphere to prepare diffusion coating. Figure 1 shows a schematic diagram of the HAPC reaction model. It can be seen that the $\mathrm{Al}_{2} \mathrm{O}_{3}$ crucible is usually used as the reaction device, and the plate on the top of the crucible plays the role of isolating air during the reaction process. The device is placed in a furnace and held at a set temperature for a certain period of time to obtain a coating on the substrate surface [24-29].

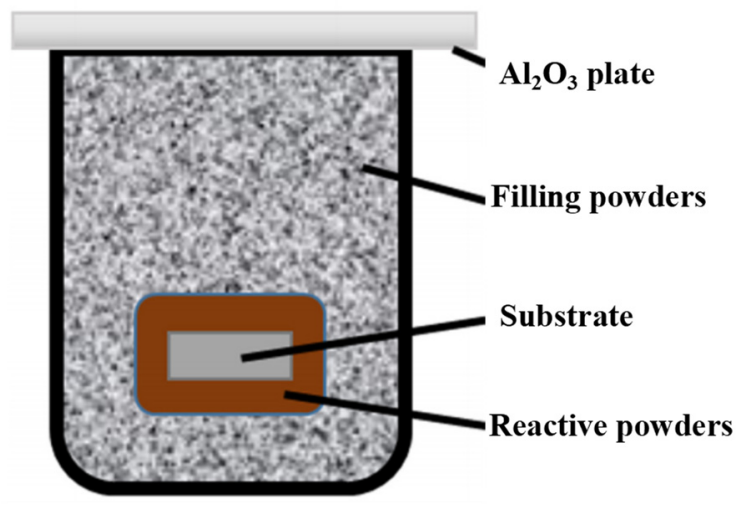

Figure 1. Schematic diagram of the reaction model of the HAPC method. Reprinted with permission from [29]; Reproduced from (Yang et al., 2018). 
Table 2 provides a summary of the process parameters, composition, and properties of HAPC coating on molybdenum-based alloys [29-42]. It can be seen that the composition of the mixture and the process conditions have an important influence on the microstructure, phase composition, grain size, and mechanical properties of the coating. Wang et al. [32] successfully prepared $\mathrm{MoSi}_{2}-\mathrm{MoB}$ coatings with an average hardness of $5.84 \mathrm{GPa}$ on Mo surface, and the hardness of MoB layer is as high as $9.54 \mathrm{GPa}$. By contrast, the surface hardness of pure $\mathrm{MoSi}_{2}$ coating is only $2.58 \mathrm{GPa}$ [34]. This is attributed to the addition of appropriate amount of $\mathrm{B}$ element in the mixed packing, which improves the fluidity of $\mathrm{Si}$ and makes the coating structure more dense and uniform [43]. The growth mechanism of HAPC coatings is shown in Figure 2. A MoSi 2 layer forms on molybdenum-based alloy, due to the interdiffusion reaction between Si powder and the substrate at high temperature. In the preparation process of coating, adding an appropriate amount of beneficial components ( $\mathrm{Al}, \mathrm{B}, \mathrm{YSZ}, \mathrm{ZrO}_{2}, \mathrm{Al}_{2} \mathrm{O}_{3}, \mathrm{SiC}, \mathrm{MoB}$, etc.) can significantly improve the oxidation resistance and mechanical properties of the silicide coatings [44-49]. The main reaction equations involved in the above process are shown in Figure $2 \mathrm{~g}$.

Table 2. Summary of process, composition, and surface properties of HAPC coatings on molybdenum and its alloy.

\begin{tabular}{|c|c|c|c|c|c|c|c|c|c|}
\hline \multirow{2}{*}{ Substrate } & \multicolumn{2}{|c|}{$\begin{array}{l}\text { Composition and Particle } \\
\text { Size of HAPC Material }\end{array}$} & \multicolumn{2}{|c|}{ Process Conditions } & \multicolumn{2}{|c|}{$\begin{array}{l}\text { Composition and } \\
\text { Thickness }(\mu \mathrm{m})\end{array}$} & \multirow{2}{*}{$\begin{array}{c}\text { Surface } \\
\text { Hardness } \\
\text { (GPa) }\end{array}$} & \multirow{2}{*}{$\begin{array}{c}\text { Grain Size } \\
\text { of Coating } \\
\text { Surface } \\
(\mu \mathrm{m})\end{array}$} & \multirow{2}{*}{ Refs. } \\
\hline & $\begin{array}{l}\text { Composition } \\
\text { (wt.\%) }\end{array}$ & $\begin{array}{l}\text { Particle } \\
\text { Size } \\
(\mu \mathrm{m})\end{array}$ & Atmosphere & $\begin{array}{l}\text { Treatment } \\
\text { Time and } \\
\text { Temperature }\end{array}$ & $\begin{array}{l}\text { Outer } \\
\text { Layer }\end{array}$ & $\begin{array}{l}\text { Interface } \\
\text { Layer }\end{array}$ & & & \\
\hline \multirow{7}{*}{ Mo } & $\mathrm{C}, \mathrm{Si}, \mathrm{NaF}$ & - & Air & $1200^{\circ} \mathrm{C}, 2 \mathrm{~h}$ & $\begin{array}{c}\mathrm{SiO}_{2-} \\
\mathrm{MoSi}_{2} \\
(55) \\
\end{array}$ & $\mathrm{Mo}_{5} \mathrm{Si}_{3}(5)$ & - & - & [29] \\
\hline & $\begin{array}{c}10 \mathrm{Si}-10 \mathrm{NH}_{4} \mathrm{~F}- \\
80 \mathrm{Al}_{2} \mathrm{O}_{3}\end{array}$ & 32.77 & $\mathrm{Ar}$ & $1300^{\circ} \mathrm{C}, 10 \mathrm{~h}$ & $\begin{array}{c}\mathrm{Al}_{2} \mathrm{O}_{3}- \\
\mathrm{MoSi}_{2} \\
(60)\end{array}$ & $\begin{array}{l}\mathrm{Mo}_{5} \mathrm{Si}_{3} \\
(1-2)\end{array}$ & - & - & \multirow[t]{3}{*}{ [30] } \\
\hline & $\begin{array}{c}10 \mathrm{Si}-10 \mathrm{NH}_{4} \mathrm{~F}- \\
80 \mathrm{SiO}_{2}\end{array}$ & 17.09 & $\mathrm{Ar}$ & $1300^{\circ} \mathrm{C}, 10 \mathrm{~h}$ & $\begin{array}{c}\mathrm{SiO} 2- \\
\mathrm{MoSi}_{2} \\
(60)\end{array}$ & $\begin{array}{l}\mathrm{Mo}_{5} \mathrm{Si}_{3} \\
(8-10)\end{array}$ & - & $10-20$ & \\
\hline & $\begin{array}{l}10 \mathrm{Si}-10 \mathrm{NH}_{4} \mathrm{~F}- \\
\quad 80 \mathrm{SiC}\end{array}$ & 4.87 & $\mathrm{Ar}$ & $1300^{\circ} \mathrm{C}, 10 \mathrm{~h}$ & $\begin{array}{l}\mathrm{SiC}-\mathrm{MoSi}_{2} \\
\quad(100)\end{array}$ & - & - & $8-10$ & \\
\hline & $\begin{array}{c}16 \mathrm{Si}-4 \mathrm{~B}-4 \mathrm{NaF}- \\
76 \mathrm{Al}_{2} \mathrm{O}_{3}\end{array}$ & - & $\mathrm{Ar}$ & $1200^{\circ} \mathrm{C}, 5 \mathrm{~h}$ & $\begin{array}{l}\mathrm{MoSi}_{2} \\
(55-59)\end{array}$ & $\begin{array}{c}\mathrm{Mo}_{5} \mathrm{Si}_{3}- \\
\mathrm{MoB}-\mathrm{Mo}_{2} \mathrm{~B} \\
(15-20)\end{array}$ & - & - & [31] \\
\hline & $\begin{array}{l}20 \mathrm{Si}-0.8 \mathrm{~B}-5 \mathrm{NaF}- \\
\quad 74.2 \mathrm{Al}_{2} \mathrm{O}_{3} \\
\end{array}$ & - & $\mathrm{Ar}$ & $1000^{\circ} \mathrm{C}, 10 \mathrm{~h}$ & $\begin{array}{l}\mathrm{MoSi}_{2} \\
(27.2)\end{array}$ & $\operatorname{MoB}(31)$ & 5.84 & - & [32] \\
\hline & $\begin{array}{c}16 \mathrm{Si}-4 \mathrm{~B}-4 \mathrm{NaF}-2 \mathrm{Y}- \\
\quad 76 \mathrm{Al}_{2} \mathrm{O}_{3}\end{array}$ & - & $\mathrm{Ar}$ & $1300^{\circ} \mathrm{C}, 5 \mathrm{~h}$ & $\mathrm{MoSi}_{2}(190)$ & $\begin{array}{c}\mathrm{Mo}_{5} \mathrm{Si}_{3}- \\
\mathrm{MoB}-\mathrm{Mo}_{2} \mathrm{~B} \\
(14)\end{array}$ & - & - & [33] \\
\hline \multirow{6}{*}{$\mathrm{TZM}$} & $\begin{array}{l}7 \mathrm{Si}-87 \mathrm{Al}_{2} \mathrm{O}_{3}- \\
6 \mathrm{NH}_{4} \mathrm{Cl}\end{array}$ & - & Vacuum & $1000^{\circ} \mathrm{C}, 12 \mathrm{~h}$ & $\mathrm{MoSi}_{2}(100)$ & $\begin{array}{l}\mathrm{Mo}_{5} \mathrm{Si}_{3} \\
(2-3)\end{array}$ & 2.58 & - & {$[34]$} \\
\hline & $\begin{array}{l}\text { 7Al-7Si-10NH }{ }_{4} \text { F- } \\
\quad 76 \mathrm{Al}_{2} \mathrm{O}_{3}\end{array}$ & $\leq 75$ & $\mathrm{Ar}$ & $1100^{\circ} \mathrm{C}, 17.5 \mathrm{~h}$ & $\mathrm{MoSi}_{2}(100)$ & $\begin{array}{l}\mathrm{Mo}(\mathrm{Si}, \mathrm{Al})_{2} \\
\quad(10)\end{array}$ & - & - & [35] \\
\hline & $\begin{array}{c}12 \mathrm{Si}-3 \mathrm{~B}-6 \mathrm{Al}- \\
2 \mathrm{Y}_{2} \mathrm{O}_{3}-5 \mathrm{NaF}- \\
72 \mathrm{Al}_{2} \mathrm{O}_{3}\end{array}$ & - & $\mathrm{Ar}$ & $1250^{\circ} \mathrm{C}, 8 \mathrm{~h}$ & $\begin{array}{l}\mathrm{Mo}(\mathrm{Si}, \mathrm{Al})_{2} \\
\quad(92)\end{array}$ & $\begin{array}{l}\mathrm{MoB}-\mathrm{Mo}_{2} \mathrm{~B} \\
\quad(2-5)\end{array}$ & - & - & [36] \\
\hline & $\begin{array}{c}\text { 7Al-7Si-10NH } \mathrm{NH}_{4} \mathrm{~F}- \\
\quad 76 \mathrm{Al}_{2} \mathrm{O}_{3}\end{array}$ & $1-2$ & $\mathrm{Ar}$ & $1300^{\circ} \mathrm{C}, 10 \mathrm{~h}$ & $\begin{array}{l}\mathrm{Mo}(\mathrm{Si}, \mathrm{Al})_{2} \\
\quad(38)\end{array}$ & $\begin{array}{c}\mathrm{Mo}_{3}(\mathrm{Al}, \mathrm{Si})- \\
\mathrm{Mo}_{5}(\mathrm{Si} \\
\mathrm{Al}_{3}(5-7)\end{array}$ & - & 0.27 & [37] \\
\hline & $\begin{array}{c}70 \mathrm{Al}_{2} \mathrm{O}_{3}-20 \mathrm{Al}- \\
10 \mathrm{NH}_{4} \mathrm{Cl}\end{array}$ & - & $\mathrm{Ar}$ & $1000^{\circ} \mathrm{C}, 12 \mathrm{~h}$ & $\begin{array}{c}\mathrm{Al}_{2} \\
\left(\mathrm{MoO}_{4}\right)_{3} \\
(20)\end{array}$ & $\begin{array}{c}\mathrm{Al}_{5} \mathrm{Mo}_{-} \\
\mathrm{Al}_{7} \mathrm{Mo}_{4} \\
\quad(30)\end{array}$ & 2.58 & - & [38] \\
\hline & $\begin{array}{l}25 \mathrm{Si}-5 \mathrm{NaF}- \\
70 \mathrm{Al}_{2} \mathrm{O}_{3}\end{array}$ & - & $\mathrm{Ar}$ & $1100^{\circ} \mathrm{C}, 6 \mathrm{~h}$ & $\mathrm{MoSi}_{2}(35)$ & $\mathrm{Mo}_{5} \mathrm{Si}_{3}(2)$ & - & - & [39] \\
\hline
\end{tabular}


Table 2. Cont.

\begin{tabular}{|c|c|c|c|c|c|c|c|c|c|}
\hline \multirow{2}{*}{ Substrate } & \multicolumn{2}{|c|}{$\begin{array}{l}\text { Composition and Particle } \\
\text { Size of HAPC Material }\end{array}$} & \multicolumn{2}{|c|}{ Process Conditions } & \multicolumn{2}{|c|}{$\begin{array}{l}\text { Composition and } \\
\text { Thickness }(\mu \mathrm{m})\end{array}$} & \multirow{2}{*}{$\begin{array}{c}\text { Surface } \\
\text { Hardness } \\
\text { (GPa) }\end{array}$} & \multirow{2}{*}{$\begin{array}{c}\text { Grain Size } \\
\text { of Coating } \\
\text { Surface } \\
(\mu \mathrm{m})\end{array}$} & \multirow{2}{*}{ Refs. } \\
\hline & $\begin{array}{l}\text { Composition } \\
\text { (wt.\%) }\end{array}$ & $\begin{array}{l}\text { Particle } \\
\text { Size } \\
(\mu \mathrm{m})\end{array}$ & Atmosphere & $\begin{array}{l}\text { Treatment } \\
\text { Time and } \\
\text { Temperature }\end{array}$ & $\begin{array}{l}\text { Outer } \\
\text { Layer }\end{array}$ & $\begin{array}{l}\text { Interface } \\
\text { Layer }\end{array}$ & & & \\
\hline & $\begin{array}{c}81 \mathrm{Al}_{2} \mathrm{O}_{3}-7 \mathrm{Si}-7 \mathrm{Al}- \\
5 \mathrm{NH}_{4} \mathrm{~F}\end{array}$ & $\leq 75$ & $\mathrm{Ar}$ & $\begin{array}{c}800-1000{ }^{\circ} \mathrm{C}, \\
8-36 \mathrm{~h}\end{array}$ & $\begin{array}{l}\mathrm{Mo}(\mathrm{Si}, \mathrm{Al})_{2} \\
\quad(20)\end{array}$ & $\begin{array}{c}\mathrm{MoSi}_{2-} \\
\mathrm{Mo}_{5} \mathrm{Si}_{3} \\
(35)\end{array}$ & - & - & [40] \\
\hline Mo-30W & $\begin{array}{l}\text { 7Al-7Si- } 5 \mathrm{NH}_{4} \mathrm{~F}- \\
81 \mathrm{Al}_{2} \mathrm{O}_{3}\end{array}$ & $\leq 75$ & $\mathrm{Ar}$ & $1000^{\circ} \mathrm{C}, 16 \mathrm{~h}$ & Al-rich (12) & $\begin{array}{c}(\mathrm{Mo}, \mathrm{W}) \mathrm{Si}_{2} \\
(46)\end{array}$ & - & - & [41] \\
\hline $\begin{array}{l}\text { Mo-9Si- } \\
8 \mathrm{~B}\end{array}$ & $\begin{array}{c}\text { 34.03Si-0.97B- } \\
2.5 \mathrm{Na}-62.5 \mathrm{Al}_{2} \mathrm{O}_{3}\end{array}$ & - & $\mathrm{Ar}$ & $1450{ }^{\circ} \mathrm{C}, 8 \mathrm{~h}$ & $\begin{array}{l}\mathrm{MoSi}_{2-} \\
\mathrm{Mo}_{5} \mathrm{Si}_{3} \\
(70)\end{array}$ & $\begin{array}{c}\mathrm{Mo}_{5} \mathrm{SiB}_{2-} \\
\mathrm{MoB} \\
(10-15)\end{array}$ & - & - & [42] \\
\hline
\end{tabular}

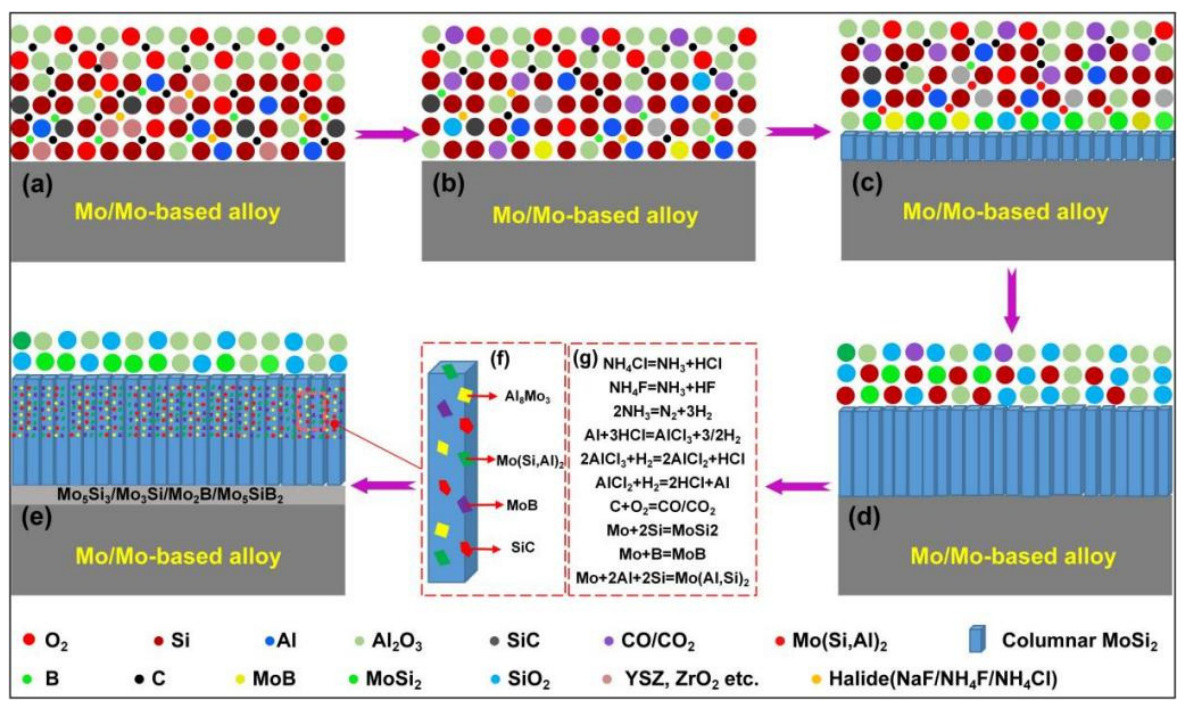

Figure 2. Growth mechanism diagram of HAPC coating on molybdenum and its alloys. (a) presedimentation, (b) Oxygen consumption in the system, (c) The initial phase of the reaction, (d) The growth stage of the coating, (e) The final structure of the coating, (f) Amplification of individual coating grains, $(\mathrm{g})$ The reactions involved in the above process.

The typical surface and cross-sectional morphology of the HAPC coatings are shown in Figure 3 [30]. It can be seen that some large particles are accumulated at the folds on the coating surface, which is mainly due to the large particle size of the mixture and uneven mixing, as shown in Figure 3a,c. The formation of micro-cracks is attributed to the thermal expansion mismatch between the coating and the substrate, as shown in Figure $3 b, c$. In addition, the addition of $\mathrm{Al}_{2} \mathrm{O}_{3}, \mathrm{SiO}_{2}$, and $\mathrm{SiC}$ has great influence on the thickness of coating and interface layer. It is shown in Figure $3 e$ that the $\mathrm{SiO}_{2}-\mathrm{MoSi}_{2}$ coating has a thick interface layer with a thickness of 8 to $10 \mu \mathrm{m}$. On the contrary, the thickness of interface layer of $\mathrm{Al}_{2} \mathrm{O}_{3}-\mathrm{MoSi}_{2}$ coating is very thin and is only 1 to $2 \mu \mathrm{m}$. It is worth noting that the $\mathrm{SiC}-\mathrm{MoSi}_{2}$ coating has the thickest coating thickness, and the interface layer is not observed, as shown in Figure $3 \mathrm{f}$. It can be seen that the addition of SiC significantly improves the deposition efficiency of the coating, which is mainly due to the physical deposition of SiC being faster than thermal diffusion deposition. 

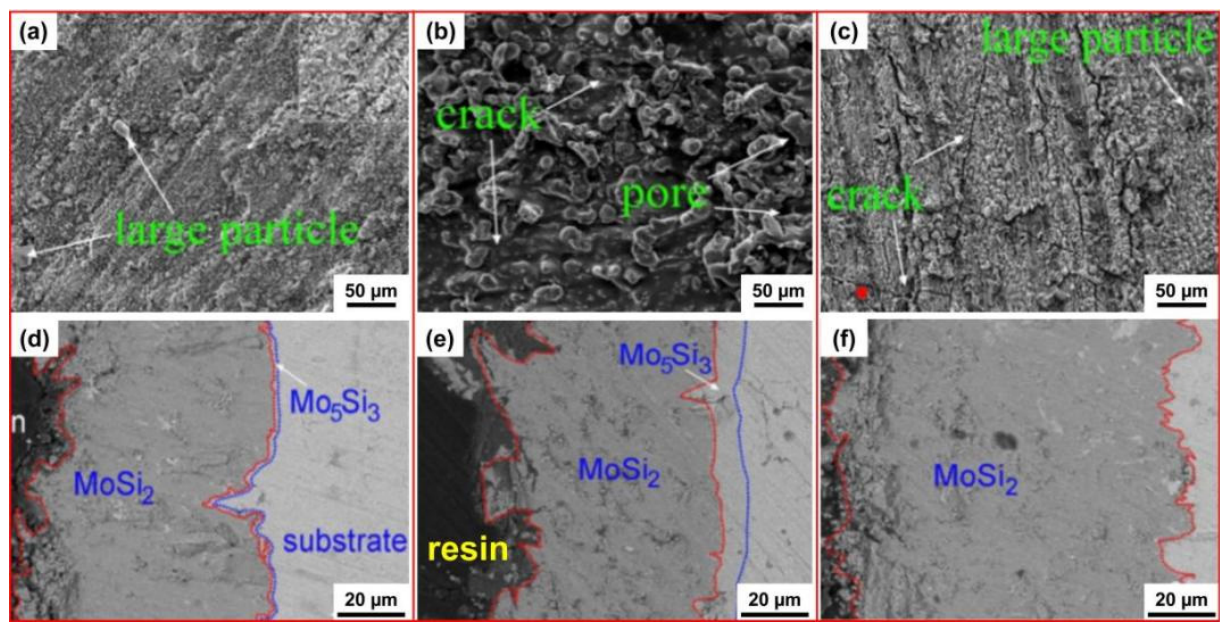

Figure 3. Surface and cross-sectional back scatter electronic (BSE) images of $\mathrm{MoSi}_{2}$ coatings prepared with $\mathrm{Al}_{2} \mathrm{O}_{3}(\mathbf{a}, \mathbf{d}), \mathrm{SiO}_{2}(\mathbf{b}, \mathbf{e})$, and $\mathrm{SiC}(\mathbf{c}, \mathbf{f})$ filler in the pack, respectively. Reprinted with permission from [30]; Reproduced from (Sun et al., 2016).

\section{Oxidation Behavior and Failure Mechanism of HAPC Coatings}

The oxidation process parameters and oxidation properties of HAPC coatings on molybdenum and its alloy are shown in Table 3. It can be seen that the ingredients of the oxide layer mainly depend on the phase composition of the original coating. The oxide layer of pure $\mathrm{MoSi}_{2}$ coatings is mainly composed of $\mathrm{SiO}_{2}$ and $\mathrm{Mo}_{5} \mathrm{Si}_{3}$, however, composite coatings are mainly composed of $\mathrm{SiO}_{2}, \mathrm{Al}_{2} \mathrm{O}_{3}$, and $\mathrm{B}_{2} \mathrm{O}_{3}$. The thickness of the outer coating decreases gradually with the increase of oxidation time. On the contrary, the thickness of the oxide layer and interface coating increases gradually, which is mainly due to the diffusion of oxygen and the internal diffusion reaction of silicon [29-42]. Figure 4 shows the typical surface and cross-section BSE images of oxidized coatings on TZM alloy. A large number of micro-cracks and $\mathrm{MoO}_{3}$ particles are observed on the surface of the oxidized $\mathrm{MoSi}_{2}$ coating, which is mainly due to the volume expansion of $\mathrm{MoO}_{3}$, as shown in Figure 4a. However, the surface structure of $\mathrm{Mo}(\mathrm{Si}, \mathrm{Al})_{2}$ coating is complete without obvious cracks and pores after oxidation. This is due to the formation of $\mathrm{Al}_{2} \mathrm{O}_{3}$ with small thermal expansion coefficient during oxidation, which inhibits the pulverization of $\mathrm{MoSi}_{2}$, as shown in Figure $5 \mathrm{~b}$ [39]. The surface of the oxidized $\mathrm{Mo}(\mathrm{Si}, \mathrm{Al})_{2}-\mathrm{MoB}$ coating is very smooth and the oxide layer is clearly visible. This is attributed to the fact that $\mathrm{SiO}_{2}-\mathrm{Al}_{2} \mathrm{O}_{3}$ generated in the oxidation process inhibits the volatilization of $\mathrm{MoO}_{3}$, and $\mathrm{MoB}$ particles are dispersed and distributed inside the $\mathrm{MoSi}_{2}$ coating, which makes the coating have a denser microstructure and better oxidation resistance, as shown in Figure 4c [38]. 
Table 3. Oxidation process parameters and oxidation properties of HAPC coatings on molybdenum and its alloys.

\begin{tabular}{|c|c|c|c|c|c|c|c|c|}
\hline \multirow{2}{*}{ Substrate } & \multicolumn{2}{|c|}{$\begin{array}{c}\text { Composition and Thickness of } \\
\text { Coatings }(\mu \mathrm{m})\end{array}$} & \multirow{2}{*}{ Exposure } & \multicolumn{3}{|c|}{$\begin{array}{c}\text { Composition and Thickness of Oxidized } \\
\text { Coatings }(\mu \mathrm{m})\end{array}$} & \multirow{2}{*}{$\begin{array}{l}\text { Mass Gain } \\
\left(\mathrm{mg} \cdot \mathrm{cm}^{-2}\right. \\
\text { wt.\%) }\end{array}$} & \multirow{2}{*}{ Refs. } \\
\hline & Outer Layer & $\begin{array}{l}\text { Interface } \\
\text { Layer }\end{array}$ & & Oxide Layer & $\begin{array}{c}\text { Intermediate } \\
\text { Layer }\end{array}$ & Interface Layer & & \\
\hline \multirow{7}{*}{ Mo } & $\mathrm{SiO}_{2}-\mathrm{MoSi}_{2}(55)$ & $\mathrm{Mo}_{5} \mathrm{Si}_{3}(5)$ & $1600{ }^{\circ} \mathrm{C}, 1 \mathrm{~h}$ & $\mathrm{SiO}_{2}-\mathrm{Mo}_{5} \mathrm{Si}_{3}$ & $\mathrm{MoSi}_{2}$ & $\mathrm{Mo}_{5} \mathrm{Si}_{3}$ & 9.86 & [29] \\
\hline & $\mathrm{Al}_{2} \mathrm{O}_{3}-\mathrm{MoSi}_{2}(60)$ & $\mathrm{Mo}_{5} \mathrm{Si}_{3}(1-2)$ & $1200^{\circ} \mathrm{C}, 110 \mathrm{~h}$ & $\mathrm{Al}_{2} \mathrm{O}_{3}(16)$ & $\mathrm{MoSi}_{2}(56)$ & $\mathrm{Mo}_{5} \mathrm{Si}_{3}(42)$ & $0.15 \%$ & \multirow{3}{*}{ [30] } \\
\hline & $\mathrm{SiO}_{2}-\mathrm{MoSi}_{2}(60)$ & $\begin{array}{c}\mathrm{Mo}_{5} \mathrm{Si}_{3} \\
(8-10)\end{array}$ & $1200^{\circ} \mathrm{C}, 110$ & $\mathrm{SiO}_{2}(8-10)$ & $\mathrm{MoSi}_{2}(32)$ & $\mathrm{Mo}_{5} \mathrm{Si}_{3}(45)$ & $0.05 \%$ & \\
\hline & SiC-MoSi 2 (100) & - & $1200^{\circ} \mathrm{C}, 110 \mathrm{~h}$ & $\mathrm{SiO}_{2}(25-30)$ & $\mathrm{MoSi}_{2}(64)$ & $\mathrm{Mo}_{5} \mathrm{Si}_{3}(40)$ & $0.28 \%$ & \\
\hline & $\mathrm{MoSi}_{2}(55-59)$ & $\begin{array}{c}\mathrm{Mo}_{5} \mathrm{Si}_{3}-\mathrm{MoB}- \\
\mathrm{Mo}_{2} \mathrm{~B} \\
(15-20)\end{array}$ & $1250^{\circ} \mathrm{C}, 100 \mathrm{~h}$ & $\begin{array}{c}\mathrm{SiO}_{2}-\mathrm{B}_{2} \mathrm{O}_{3}- \\
\mathrm{MoO}_{3} \\
(100)\end{array}$ & $\mathrm{Mo}_{5} \mathrm{SiB}_{2}(20)$ & $\begin{array}{c}\mathrm{Mo}_{5} \mathrm{Si}_{3}-\mathrm{MoB}- \\
\mathrm{Mo}_{2} \mathrm{~B} \\
(50)\end{array}$ & 3.25 & [31] \\
\hline & $\mathrm{MoSi}_{2}(27.2)$ & $\operatorname{MoB}(31)$ & $1300^{\circ} \mathrm{C}, 80 \mathrm{~h}$ & $\mathrm{SiO}_{2}(6-8)$ & $\begin{array}{c}\mathrm{MoSi}_{2-}- \\
\mathrm{Mo}_{5} \mathrm{Si}_{3} \\
(50)\end{array}$ & $\mathrm{MoB}-\mathrm{Mo}_{2} \mathrm{~B}(38)$ & 0.34 & [32] \\
\hline & $\mathrm{MoSi}_{2}(190)$ & $\begin{array}{c}\mathrm{Mo}_{5} \mathrm{Si}_{3}-\mathrm{MoB}- \\
\mathrm{Mo}_{2} \mathrm{~B}(14)\end{array}$ & $\begin{array}{l}1000^{\circ} \mathrm{C}, 100 \mathrm{~h}, \\
1 \mathrm{~h} \text { cycles }\end{array}$ & $\mathrm{SiO}_{2}(16)$ & $\mathrm{MoSi}_{2}(80)$ & $\begin{array}{c}\mathrm{Mo}_{5} \mathrm{Si}_{3}-\mathrm{MoB}- \\
\mathrm{Mo}_{2} \mathrm{~B} \\
(32)\end{array}$ & $1.33 \times 10^{-3}$ & [33] \\
\hline \multirow{7}{*}{$\mathrm{TZM}$} & $\mathrm{MoSi}_{2}(100)$ & $\mathrm{Mo}_{5} \mathrm{Si}_{3}(2-3)$ & $1200^{\circ} \mathrm{C}, 55 \mathrm{~h}$ & - & - & - & 0.15 & [34] \\
\hline & $\mathrm{MoSi}_{2}(100)$ & $\begin{array}{l}\mathrm{Mo}(\mathrm{Si}, \mathrm{Al})_{2} \\
\quad(10)\end{array}$ & $\begin{array}{l}1100^{\circ} \mathrm{C}, 250 \mathrm{~h}, \\
0.5 \mathrm{~h} \text { cycles }\end{array}$ & $\begin{array}{l}\mathrm{SiO}_{2}-\mathrm{Al}_{2} \mathrm{O}_{3} \\
\quad(5-8)\end{array}$ & $\mathrm{MoSi}_{2}(45)$ & $\mathrm{Mo}(\mathrm{Si}, \mathrm{Al})_{2}(20)$ & 0.08 & [35] \\
\hline & $\mathrm{Mo}(\mathrm{Si}, \mathrm{Al})_{2}(92)$ & $\begin{array}{l}\mathrm{MoB}-\mathrm{Mo}_{2} \mathrm{~B} \\
\quad(2-5)\end{array}$ & $1400^{\circ} \mathrm{C}, 25 \mathrm{~h}$ & $\begin{array}{l}\mathrm{SiO}_{2}-\mathrm{Al}_{2} \mathrm{O}_{3} \\
\quad(15-20)\end{array}$ & $\begin{array}{l}\mathrm{MoSi}_{2}-\mathrm{MoB} \\
\quad(88)\end{array}$ & $\begin{array}{l}\mathrm{Mo}_{5} \mathrm{Si}_{3}-\mathrm{Mo}_{2} \mathrm{~B} \\
(28)\end{array}$ & 2.38 & [36] \\
\hline & $\mathrm{Mo}(\mathrm{Si}, \mathrm{Al})_{2}(38)$ & $\begin{array}{c}\mathrm{Mo}_{3}(\mathrm{Al}, \mathrm{Si})- \\
\mathrm{Mo}_{5}(\mathrm{Si}, \mathrm{Al})_{3} \\
(5-7)\end{array}$ & $1100^{\circ} \mathrm{C}, 10 \mathrm{~h}$ & $\begin{array}{l}\mathrm{SiO}_{2}-\mathrm{Al}_{2} \mathrm{O}_{3} \\
\quad(2.5)\end{array}$ & $\begin{array}{l}\mathrm{Mo}(\mathrm{Si}, \mathrm{Al})_{2} \\
\quad(50)\end{array}$ & $\begin{array}{c}\mathrm{Mo}_{3}(\mathrm{Al}, \mathrm{Si})- \\
\mathrm{Mo}_{5}(\mathrm{Si}, \mathrm{Al})_{3}(20)\end{array}$ & 12.92 & [37] \\
\hline & $\mathrm{Al}_{2}\left(\mathrm{MoO}_{4}\right)_{3}(20)$ & $\begin{array}{c}\mathrm{Al}_{5} \mathrm{Mo}^{-} \\
\mathrm{Al}_{7} \mathrm{Mo}_{4} \\
(30)\end{array}$ & $1200^{\circ} \mathrm{C}, 50 \mathrm{~h}$ & - & - & - & 0.15 & [38] \\
\hline & $\mathrm{MoSi}_{2}(35)$ & $\mathrm{Mo}_{5} \mathrm{Si}_{3}(2)$ & $1350^{\circ} \mathrm{C}, 20 \mathrm{~h}$ & $\mathrm{SiO}_{2}(1-2)$ & $\mathrm{MoSi}_{2}(20)$ & $\mathrm{Mo}_{5} \mathrm{Si}_{3}(50)$ & 0.16 & [39] \\
\hline & $\mathrm{Mo}(\mathrm{Si}, \mathrm{Al})_{2}(20)$ & $\begin{array}{c}\mathrm{MoSi}_{2-} \\
\mathrm{Mo}_{5} \mathrm{Si}_{3} \\
(35)\end{array}$ & $1300^{\circ} \mathrm{C}, 72 \mathrm{~h}$ & $\begin{array}{l}\mathrm{SiO}_{2}-\mathrm{Al}_{2} \mathrm{O}_{3} \\
\quad(5-10)\end{array}$ & - & - & 0.694 & [40] \\
\hline Mo-30W & Al-rich (12) & $\begin{array}{l}(\mathrm{Mo}, \mathrm{W}) \mathrm{Si}_{2} \\
(46)\end{array}$ & $1100^{\circ} \mathrm{C}, 15 \mathrm{~h}$ & - & - & - & - & [41] \\
\hline $\begin{array}{l}\text { Mo-9Si- } \\
\text { 8B }\end{array}$ & $\begin{array}{l}\mathrm{MoSi}_{2}-\mathrm{Mo}_{5} \mathrm{Si}_{3} \\
\text { (70) }\end{array}$ & $\begin{array}{c}\mathrm{Mo}_{5} \mathrm{SiB}_{2}- \\
\mathrm{MoB} \\
(10-15)\end{array}$ & $1300^{\circ} \mathrm{C}, 100 \mathrm{~h}$ & $\begin{array}{l}\mathrm{SiO}_{2}-\mathrm{B}_{2} \mathrm{O}_{3} \\
\quad(25)\end{array}$ & $\begin{array}{l}\mathrm{MoSi}_{2}-\mathrm{Mo} \\
\quad(40)\end{array}$ & $\begin{array}{c}\mathrm{Mo}_{5} \mathrm{Si}_{3}-\mathrm{MoB}- \\
\mathrm{Mo}_{5} \mathrm{SiB}_{2} \\
(75)\end{array}$ & 3.82 & [42] \\
\hline
\end{tabular}

In addition, Sun et al. compared the oxidation kinetics curves of the pure Mo and the $\mathrm{MoSi}_{2}$ coatings prepared with $\mathrm{Al}_{2} \mathrm{O}_{3}, \mathrm{SiO}_{2}$, and $\mathrm{SiC}$ filler in the pack, respectively, at different temperatures, as shown in Figure 5 [30]. It can be seen that after oxidizing at $500{ }^{\circ} \mathrm{C}$ for $110 \mathrm{~h}$, the quality of the deposited coating only changes from $-0.18 \%-0.09 \%$. Among them, the quality of the deposited $\mathrm{SiC}$ coating has little change before and after oxidation. However, the mass variation of Mo substrate under this condition is as high as $3 \%$, as shown in Figure 5a,b. Furthermore, in the oxidation experiments at $1200{ }^{\circ} \mathrm{C}$, the Mo substrate rapidly failed in the initial stage of oxidation, and the quality of the deposited $\mathrm{Al}_{2} \mathrm{O}_{3}, \mathrm{SiO}_{2}$ coatings are Increases of varying degrees, respectively. However, the mass of deposited $\mathrm{SiC}$ coating increases first and then decreases under the oxidation conditions. This is caused by the formation and evaporation of oxidized carbon $\left(\mathrm{CO}, \mathrm{CO}_{2}\right)$ during oxidation, as shown in Figure 5c. 

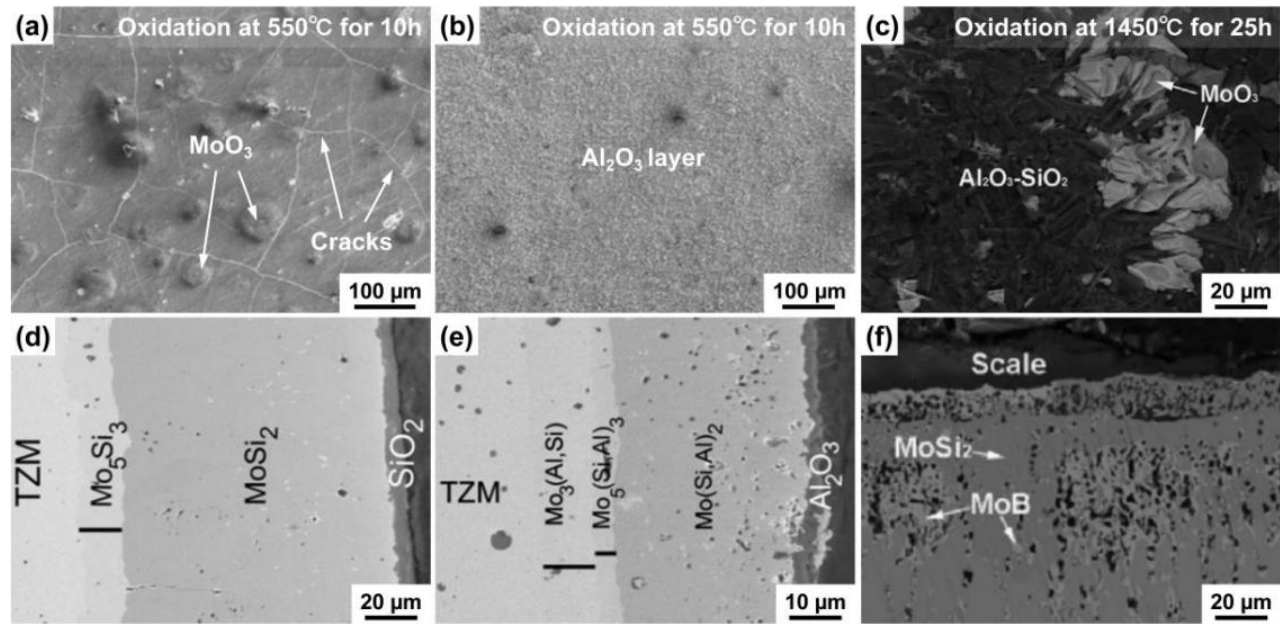

Figure 4. Surface and cross-section images of HAPC coatings at different Oxidation conditions; (a,d) $\mathrm{MoSi}_{2}$ coating, (b,e) $\mathrm{Mo}(\mathrm{Si}, \mathrm{Al})_{2}$ coating. Reprinted with permission from [39]; Reproduced from (Paul et al., 2014). (c,f) Mo(Si,Al) $)_{2}-\mathrm{MoB}$ coating. Reprinted with permission from [38]; Reproduced from (Chakraborty et al., 2008).
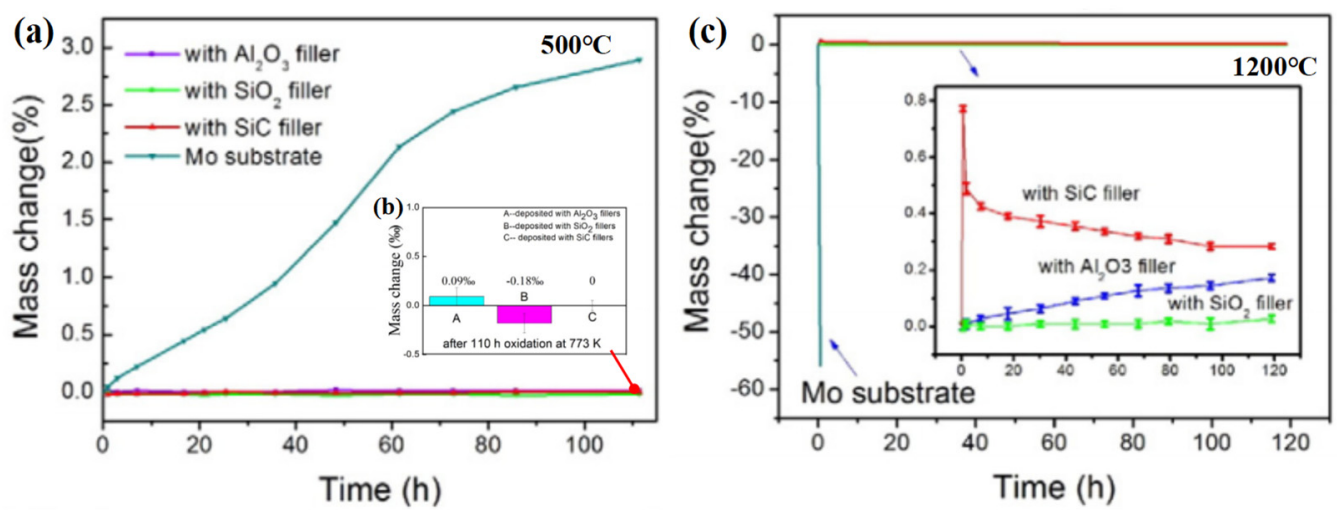

Figure 5. The oxidation kinetics in terms of time of exposure as well as temperature of Mo substrate and coatings at different temperatures, (a) $500{ }^{\circ} \mathrm{C},(\mathbf{b})$ is the local amplification at $110 \mathrm{~h}$ as shown in $(\mathbf{a}, \mathbf{c}) 1200^{\circ} \mathrm{C}$. Reprinted with permission from [30]; Reproduced from (Sun et al., 2016).

The microstructure evolution and oxidation mechanism of the coating are shown in Figure 6. Generally, the oxidation of the coating can be divided into transient oxidation and steady oxidation [50]. At the initial stage of oxidation, $\mathrm{Mo}, \mathrm{Si}, \mathrm{B}, \mathrm{Al}$, and other elements are oxidized at the same time. The quality loss of the coating is faster with the formation and volatilization of $\mathrm{MoO}_{3}$, and the $\mathrm{SiO}_{2}$ layer is discontinuous at this stage. At the same time, a large number of pores were observed on the coating surface after the evaporation of $\mathrm{MoO}_{3}$. With the progress of oxidation reaction, continuous and dense oxide films $\left(\mathrm{Al}_{2} \mathrm{O}_{3}\right.$, $\mathrm{SiO}_{2}, \mathrm{~B}_{2} \mathrm{O}_{3}-\mathrm{SiO}_{2}$, etc.) gradually form on the coating surface. At last, a large number of pores are closed by $\mathrm{SiO}_{2}$ with a low oxidation rate, and the oxidation process changes to a steady state [51,52]. 


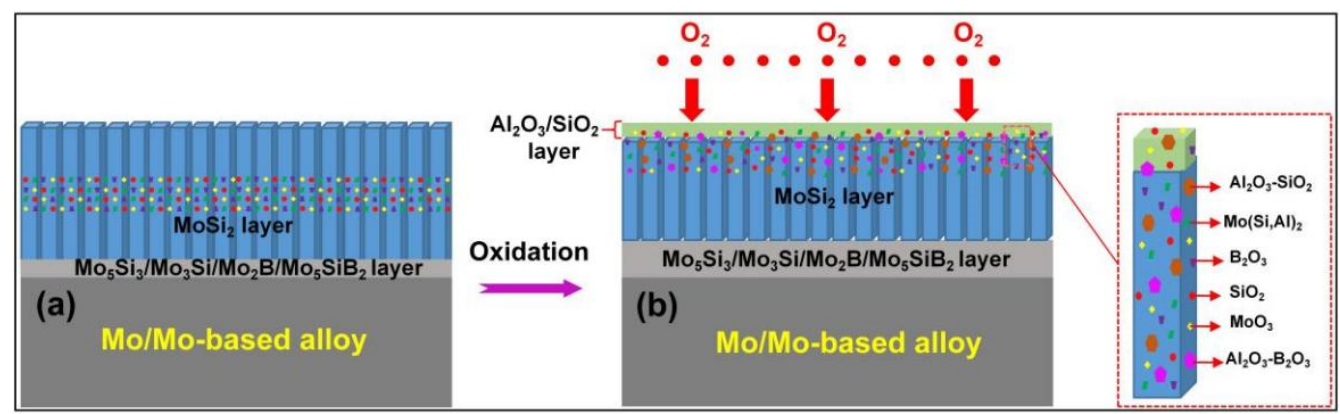

Figure 6. Oxidation mechanism diagram of HAPC coatings on molybdenum and its alloys. (a) Initial oxidation stage, (b) Late oxidation stage of coating.

\section{Conclusions and Prospects}

In this work, the growth mechanism, oxidation behavior, and mechanism of HAPC coatings are analyzed and discussed. The process conditions and properties of the coatings are provided. During the process, due to the relatively low process temperature of HAPC methods, the deposition efficiency of the coating is low, and the preparation time is long. However, the application of the processes is not limited by the shape of the substrate, and the coatings prepared have a uniform composition and good adhesion to the substrate. Figure 7 provides a summary of the composition and oxidation characteristics of protective coatings prepared by many researchers on the surface of molybdenum and its alloys by HAPC method.

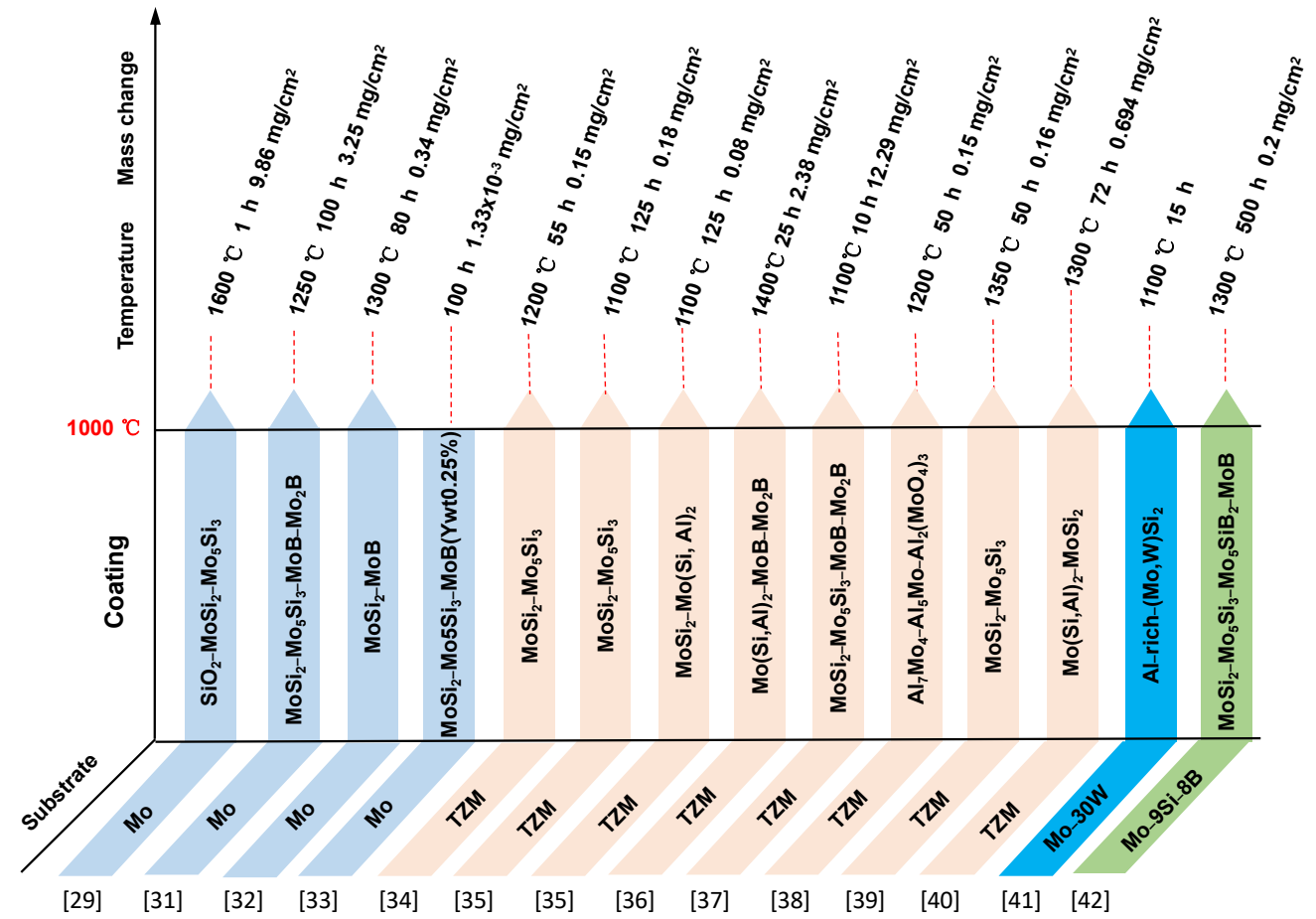

Figure 7. Overview of the composition and oxidation characteristics of HAPC coatings on the surface of Mo and its alloys.

In addition, the addition of beneficial elements and the second phases can not only significantly improve the mechanical properties and high temperature oxidation resistance of the coating, but also can delay the diffusion of silicon to the substrate, inhibit the formation of $\mathrm{Mo}_{5} \mathrm{Si}_{3}$ with poor oxidation resistance, reduce the formation of volatile $\mathrm{MoO}_{3}$, and promote the rapid formation of continuous and dense anti-oxidation film on the 
coating surface. The addition of $\mathrm{Al}$ element can significantly inhibit the formation of the pulverization $\mathrm{MoO}_{3}$ and the occurrence of pulverization, which is mainly due to the formation of $\mathrm{Al}_{2} \mathrm{O}_{3}$ with low thermal expansion coefficient. The addition of $\mathrm{B}$ element can improve the oxidation resistance of the coating mainly in the following two aspects. On the one hand, in the process of high temperature oxidation (above $1400^{\circ} \mathrm{C}$ ), an appropriate amount of $\mathrm{B}$ dissolved into the oxide layer can further improve the fluidity of $\mathrm{SiO}_{2}$, which promotes the healing of pores and cracks. On the other hand, MoB reacts with Si to produce $\mathrm{Mo}_{5} \mathrm{SiB}_{2}$ with low diffusion coefficient, which delays the diffusion of $\mathrm{Si}$ to the substrate and improves the oxidation life of the coating. In addition, $\mathrm{Cr}$ and $\mathrm{W}$ elements can also improve the oxidation resistance of the coating, which is mainly due to the formation of $\mathrm{Cr}_{2} \mathrm{O}_{3}$ with high oxidation resistance, and the formation of $(\mathrm{Mo}, \mathrm{W}) \mathrm{Si}_{2}$ phase inhibits the internal diffusion of silicon into the substrate.

In order to improve the mechanical properties and antioxidant properties of the coating, the microstructure and phase composition of the coating must be optimized, and the addition of the second reinforcing phase also plays a positive role. Moreover, the multi-step coating preparation process can organically combine the single coating preparation technology with each other, overcome the limitations of its single application, and effectively extend the oxidation service life of the coating. This will be the direction of future research and development in this field.

Author Contributions: The manuscript was written through contributions of all authors. Y.Z.: Conceptualization, Investigation, and Supervision. Y.Z. and T.F.: Writing original draft and image processing. T.F., K.C., L.Y. and J.W.: Validation, Resources, Investigation, Writing-review \& editing. X.Z., H.M. and F.S.: Visualization, Writing-review \& editing. All authors have given approval to the final version of the manuscript.

Funding: This research was funded by the National Natural Science Foundation of China, Grant No. 51604049.

Institutional Review Board Statement: Not applicable.

Informed Consent Statement: Not applicable.

Data Availability Statement: The study did not report any data.

Conflicts of Interest: The authors declare that they have no known competing financial interests or personal relationships that could have appeared to influence the work reported in this paper.

\section{References}

1. Chaudhuri, A.; Behera, A.N.; Sarkar, A.; Kapoor, R.; Ray, R.K.; Suwas, S. Hot deformation behaviour of Mo-TZM and understanding the restoration processes involved. Acta Mater. 2019, 164, 153-164. [CrossRef]

2. Tuzemen, C.; Yavas, B.; Akin, I.; Yucel, O.; Sahin, F.; Goller, G. Production and characterization of TZM based TiC or ZrC reinforced composites prepared by spark plasma sintering (SPS). J. Alloys Compd. 2019, 781, 433-439. [CrossRef]

3. Sharma, I.; Chakraborty, S.; Suri, A. Preparation of TZM alloy by aluminothermic smelting and its characterization. J. Alloys Compd. 2005, 393, 122-127. [CrossRef]

4. Majumdar, S.; Kale, G.; Sharma, I. A study on preparation of Mo-30W alloy by aluminothermic co-reduction of mixed oxides. J. Alloys Compd. 2005, 394, 168-175. [CrossRef]

5. Xu, J.; Yang, T.; Yang, Y.; Qian, Y.; Li, M.; Yin, X. Ultra-high temperature oxidation behavior of micro-laminated ZrC/MoSi 2 coating on C/C composite. Corros. Sci. 2018, 132, 161-169. [CrossRef]

6. Cui, K.K.; Fu, T.; Zhang, Y.Y.; Wang, J.; Mao, H.B.; Tan, T.B. Microstructure and mechanical properties of $\mathrm{CaAl}_{12} \mathrm{O}_{19}$ reinforced $\mathrm{Al}_{2} \mathrm{O}_{3}-\mathrm{Cr}_{2} \mathrm{O}_{3}$ composites. J. Eur. Ceram. Soc. 2021, in press. [CrossRef]

7. Kong, H.; Kwon, H.S.; Kim, H.; Jeen, G.-S.; Lee, J.; Lee, J.; Heo, Y.S.; Cho, J.-H.; Jeen, H.; Kim, H. Reductive-annealing-induced changes in Mo valence states on the surfaces of $\mathrm{MoO}_{3}$ single crystals and their high temperature transport. Curr. Appl. Phys. 2019, 19, 1379-1382. [CrossRef]

8. Peña-Bahamonde, J.; Wu, C.; Fanourakis, S.K.; Louie, S.M.; Bao, J.; Rodrigues, D.F. Rodrigues, Oxidation state of Mo affects dissolution and visible-light photocatalytic activity of $\mathrm{MoO}_{3}$ nanostructures. J. Catal. 2020, 381, 508-519. [CrossRef]

9. Smolik, G.; Petti, D.; Schuetz, S. Oxidation and volatilization of TZM alloy in air. J. Nucl. Mater. 2000, 283-287, 1458-1462. [CrossRef]

10. Majumdar, S.; Kapoor, R.; Raveendra, S.; Sinha, H.; Samajdar, I.; Bhargava, P.; Chakravartty, J.; Sharma, I.; Suri, A. A study of hot deformation behavior and microstructural characterization of Mo-TZM alloy. J. Nucl. Mater. 2009, 385, 545-551. [CrossRef] 
11. Zhang, Y.; Zhao, J.; Li, J.; Lei, J.; Cheng, X. Effect of hot-dip siliconizing time on phase composition and microstructure of Mo-MoSi 2 high temperature structural materials. Ceram. Int. 2019, 45, 5588-5593. [CrossRef]

12. Zhang, Y.; Hussain, S.; Cui, K.; Fu, T.; Wang, J.; Javed, M.S.; Lv, Y.; Aslam, B. Microstructure and mechanical properties of MoSi 2 coating deposited on Mo substrate by hot dipping processes. J. Nanoelectron. Optoelectron. 2019, 14, 1680-1685. [CrossRef]

13. Cui, K.; Zhang, Y.; Fu, T.; Hussain, S.; Algarni, T.S.; Wang, J.; Zhang, X.; Ali, S. Effects of $\mathrm{Cr}_{2} \mathrm{O}_{3}$ Content on Microstructure and Mechanical Properties of $\mathrm{Al}_{2} \mathrm{O}_{3}$ Matrix Composites. Coatings 2021, 11, 234. [CrossRef]

14. Liu, L.; Lei, H.; Gong, J.; Sun, C. Deposition and oxidation behaviour of molybdenum disilicide coating on $\mathrm{Nb}$ based alloys substrate by combined AIP/HAPC processes. Ceram. Int. 2019, 45, 10525-10529. [CrossRef]

15. Cui, Y.; Derby, B.; Li, N.; Misra, A. Fracture resistance of hierarchical Cu-Mo nanocomposite thin films. Mater. Sci. Eng. A 2021, 799, 139891. [CrossRef]

16. Zhang, Y.Y.; Cui, K.K.; Fu, T.; Wang, J.; Shen, F.Q.; Zhang, X.; Yu, L.H. Formation of $\mathrm{MoSi}_{2}$ and Si/MoSi 2 coatings on TZM (Mo-0.5Ti-0.1Zr-0.02C) alloy by hot dip silicon-plating method. Ceram. Int. 2021, 47, 23053-23065. [CrossRef]

17. Mannheim, R.; Garin, J. Structural identification of phases in Mo-Re alloys within the range from 5 to $95 \%$ Re. J. Mater. Process. Technol. 2003, 143-144, 533-538. [CrossRef]

18. Li, W.; Wei, L.; He, J.; Chen, H.; Guo, H. The role of Re in improving the oxidation-resistance of a Re modified Pt-Al coating on Mo-rich single crystal superalloy. J. Mater. Sci. Technol. 2020, 58, 63-72. [CrossRef]

19. Zhang, Y.Y.; Qie, J.M.; Cui, K.K.; Fu, T.; Fan, X.L.; Wang, J.; Zhang, X. Effect of hot dip silicon-plating temperature on microstructure characteristics of silicide coating on tungsten substrate. Ceram. Int. 2020, 46, 5223-5228. [CrossRef]

20. Zhang, Y.; Cui, K.; Gao, Q.; Hussain, S.; Lv, Y. Investigation of morphology and texture properties of WSi 2 coatings on W substrate based on contact-mode AFM and EBSD. Surf. Coat. Technol. 2020, 396, 125966. [CrossRef]

21. Zhang, Y.; Li, Y.; Bai, C. Microstructure and oxidation behavior of Si-MoSi 2 functionally graded coating on Mo substrate Ceram. Int. 2017, 43, 6250-6256. [CrossRef]

22. Zhang, Y.; Cui, K.; Fu, T.; Wang, J.; Qie, J.; Zhang, X. Synthesis WSi 2 coating on W substrate by HDS method with various deposition times. Appl. Surf. Sci. 2020, 511, 145551. [CrossRef]

23. Zhang, Y.; Fu, T.; Cui, K.; Shen, F.; Wang, J.; Yu, L.; Mao, H. Evolution of surface morphology, roughness and texture of tungsten disilicide coatings on tungsten substrate. Vacuum 2021, 191, 110297. [CrossRef]

24. Fu, T.; Cui, K.; Zhang, Y.; Wang, J.; Shen, F.; Yu, L.; Qie, J.; Zhang, X. Oxidation protection of tungsten alloys for nuclear fusion applications: A comprehensive review. J. Alloys Compd. 2021, 884, 161057. [CrossRef]

25. Majumdar, S.; Raveendra, S.; Samajdar, I.; Bhargava, P.; Sharma, I. Densification and grain growth during isothermal sintering of Mo and mechanically alloyed Mo-TZM. Acta Mater. 2009, 57, 4158-4168. [CrossRef]

26. $\mathrm{Hu}, \mathrm{D} . ; \mathrm{Fu}, \mathrm{Q}$; Zhou, L.; Zhang, Y.; Zhang, G. Stress design of a laminated $\mathrm{MoSi}_{2} / \mathrm{Cr}$ coating under particle impact and high temperature environment. Ceram. Int. 2020, 46, 10696-10703. [CrossRef]

27. Pang, J.; Wang, W.; Zhou, C. Microstructure evolution and oxidation behavior of B modified MoSi ${ }_{2}$ coating on Nb-Si based alloys. Corros. Sci. 2016, 105, 1-7. [CrossRef]

28. Sun, J.; Li, T.; Zhang, G.-P.; Fu, Q.-G. Different oxidation protection mechanisms of HAPC silicide coating on niobium alloy over a large temperature range. J. Alloys Compd. 2019, 790, 1014-1022. [CrossRef]

29. Yang, K.-M.; Wang, J.-X.; Yang, S.-Y.; Zhang, X.-L.; Luo, P. In-situ synthesis of $\mathrm{MoSi}_{2}$ coating on Mo substrate under carbon protection and its short-term oxidation behavior. Surf. Coat. Technol. 2018, 354, 324-329. [CrossRef]

30. Sun, J.; Fu, Q.-G.; Guo, L.-P.; Liu, Y.; Huo, C.-X.; Li, H.-J. Effect of filler on the oxidation protective ability of MoSi ${ }_{2}$ coating for Mo substrate by halide activated pack cementation. Mater. Des. 2016, 92, 602-609. [CrossRef]

31. Tian, X.; Guo, X.; Sun, Z.; Yin, Z.; Wang, L. Formation of B-modified $\mathrm{MoSi}_{2}$ coating on pure Mo prepared through HAPC process Int. J. Refract. Met. Hard Mater. 2014, 45, 8-14. [CrossRef]

32. Wang, Y.; Wang, D.; Yan, J. Preparation and characterization of $\mathrm{MoSi}_{2}$ / MoB composite coating on Mo substrate. J. Alloys Compd. 2014, 589, 384-388. [CrossRef]

33. Tian, X.; Guo, X.; Sun, Z.; Li, M.; Wang, L. Effects of $\mathrm{Y}_{2} \mathrm{O}_{3} / \mathrm{Y}$ on Si-B co-deposition coating prepared through HAPC method on pure molybdenum. J. Rare Earths 2016, 34, 952-957. [CrossRef]

34. Chakraborty, S.; Banerjee, S.; Sharma, I.; Suri, A. Development of silicide coating over molybdenum based refractory alloy and its characterization. J. Nucl. Mater. 2010, 403, 152-159. [CrossRef]

35. Majumdar, S. Formation of $\mathrm{MoSi}_{2}$ and $\mathrm{Al}$ doped $\mathrm{MoSi}_{2}$ coatings on molybdenum base TZM (Mo-0.5Ti-0.1Zr-0.02C) alloy Surf. Coat. Technol. 2012, 206, 3393-3398. [CrossRef]

36. Zhang, P.; Guo, X.; Ren, X.; Chen, Z.; Shen, C. Development of $\mathrm{Mo}(\mathrm{Si}, \mathrm{Al})_{2}-\mathrm{MoB}$ composite coatings to protect TZM alloy against oxidation at $1400{ }^{\circ} \mathrm{C}$. Intermetallics 2018, 93, 134-140. [CrossRef]

37. Majumdar, S.; Sharma, I. Oxidation behavior of $\mathrm{MoSi}_{2}$ and $\mathrm{Mo}(\mathrm{Si}, \mathrm{Al})_{2}$ coated Mo-0.5Ti-0.1Zr-0.02C alloy. Intermetallics 2011, 19, 541-545. [CrossRef]

38. Chakraborty, S.; Banerjee, S.; Singh, K.; Sharma, I.; Grover, A.; Suri, A. Studies on the development of protective coating on TZM alloy and its subsequent characterization. J. Mater. Process. Technol. 2008, 207, 240-247. [CrossRef]

39. Paul, B.; Limaye, P.; Hubli, R.; Suri, A. Microstructure and wear properties of silicide based coatings over Mo-30W alloy. Int. J. Refract. Met. Hard Mater. 2014, 44, 77-83. [CrossRef] 
40. Majumdar, S.; Sharma, I.; Raveendra, S.; Samajdar, I.; Bhargava, P. In situ chemical vapour co-deposition of Al and Si to form diffusion coatings on TZM. Mater. Sci. Eng. A 2008, 492, 211-217. [CrossRef]

41. Majumdar, S.; Sharma, I.; Suri, A. Development of oxidation resistant coatings on Mo-30W alloy. Int. J. Refract. Met. Hard Mater. 2008, 26, 549-554. [CrossRef]

42. Lange, A.; Heilmaier, M.; Sossamann, T.A.; Perepezko, J.H. Oxidation behavior of pack-cemented Si-B oxidation protection coatings for Mo-Si-B alloys at $1300{ }^{\circ} \mathrm{C}$. Surf. Coat. Technol. 2015, 266, 57-63. [CrossRef]

43. Paul, B.; Kishor, J.; Majumdar, S.; Kain, V. Studies on growth mechanism of intermediate layer of (Mo,W)5Si3 and interdiffusion in the $(\mathrm{Mo}, \mathrm{W})-(\mathrm{Mo}, \mathrm{W}) \mathrm{Si}_{2}$ system prepared by pack cementation coating. Surf. Interfaces 2020, 18, 100458. [CrossRef]

44. Burk, S.; Gorr, B.; Christ, H.-J. High temperature oxidation of Mo-Si-B alloys: Effect of low and very low oxygen partial pressures. Acta Mater. 2010, 58, 6154-6165. [CrossRef]

45. Pan, Y. The structural, mechanical and thermodynamic properties of the orthorhombic TMAl (TM=Ti, Y, Zr and Hf) aluminides from first-principles calculations. Vacuum 2020, 181, 109742. [CrossRef]

46. Pan, Y.; Guan, W. The hydrogenation mechanism of PtAl and IrAl thermal barrier coatings from first-principles investigations. Int. J. Hydrogen Energy 2020, 45, 20032-20041. [CrossRef]

47. Zhang, X.; Fu, T.; Cui, K.; Zhang, Y.; Shen, F.; Wang, J.; Yu, L.; Mao, H. Coatings The Protection, Challenge, and Prospect of Anti-Oxidation Coating on the Surface of Niobium Alloy. Coatings 2021, 11, 742. [CrossRef]

48. Liu, Y.; Shao, W.; Wang, C.L.; Zhou, C.G. Microstructure and oxidation behavior of Mo-Si-Al coating on Nb-based alloy. J. Alloys Compd. 2018, 735, 2247-2255. [CrossRef]

49. Huang, L.; Pan, Y.; Zhang, J.; Du, Y.; Luo, F.; Zhang, S. CALPHAD-type modeling of the C-Hf-Mo system over the whole composition and temperature ranges. Thermochim. Acta 2020, 692, 178716. [CrossRef]

50. Qiao, Y.Q.; Kong, J.P.; Xi, Q.L.; Guo, P. Comparison of two kinds of Si-B-Y co-deposition coatings on an Nb-Ti-Si based alloy by pack cementation method. Surf. Coat. Technol. 2017, 327, 93-100. [CrossRef]

51. Paswan, S.; Mitra, R.; Roy, S. Oxidation behaviour of the Mo-Si-B and Mo-Si-B-Al alloys in the temperature range of $700-1300{ }^{\circ} \mathrm{C}$. Intermetallics 2007, 15, 1217-1227. [CrossRef]

52. Tian, X.; Guo, X. Structure and oxidation behavior of Si-Y co-deposition coatings on an Nb silicide based ultrahigh temperature alloy prepared by pack cementation technique. Surf. Coat. Technol. 2009, 204, 313-318. [CrossRef] 